\title{
LYMPHOCYTE PROLIFERATION ON HYPERSENSITIVITY OF Balb/C MICE AFTER GIVEN ETHANOL EXTRACT TUBER OF Dioscorea alata L.
}

\author{
Sri Nabawiyati Nurul Makiyah, ${ }^{1}$ Moch. Sasmito Djati, ${ }^{2}$ Muhaimin Rifa'i, ${ }^{2}$ Widodo ${ }^{2}$ \\ ${ }^{1}$ Department of Histology \& Cell Biology, Faculty Medicine \& Health Science, University Muhammadiyah of \\ Yogyakarta; ${ }^{1}$ Postgraduate Student of Biology Department Faculty of Mathematic and Sciences, Brawijaya \\ University Malang; ${ }^{2}$ Biology Department, Faculty of Mathematic and Sciences, Brawijaya University Malang \\ Email: nurul_makiyah@umy.ac.id / nurul_mkyh@yahoo.co.id \\ Address: Department of Histology \& Cell Biology, Faculty Medicine \& Health Sciences, \\ University Muhammadiyah of Yogyakarta, Jl. Lingkar Selatan, Tamantirto, Kasihan, Bantul DIY 55183
}

\begin{abstract}
Purple yam (Dioscorea alata L.) is a source nutritious tubers that has not been used optimally. Nutrients content in Dioscorea species are starch, essentials amino acid, minerals, polyphenol, glycoprotein, purin derivates such as allantoin, and steroid saponin which have biological activity such as immunomodulatory and antiallergic. The purpose of this research was to assess the absolute number of lymphocyte on hypersensitivity of mice after treated with ethanol extract of $D$. alata. Twenty one male Balb/C mice were used which were divided into seven groups: control (C), negative control (NC), treatments with ethanol extract

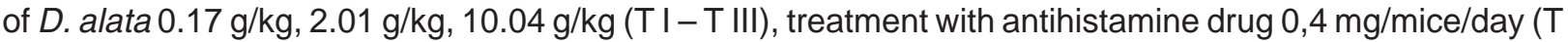
IV) and treatment with diosgenin $200 \mathrm{mg} / \mathrm{kg}$ (T V). For 17 consecutive days the T I - T III groups were treated with ethanol extract of $D$. alata correspond to their doses, T IV group were treated with antihistamine drugs, and $\mathrm{T} V$ group were treated with diosgenin. On day 15, NC and T I - T V groups of mice were induced by ovalbumin $0,0483 \mathrm{mg} / \mathrm{mice}$. Mice were sacrificed on day 18 , and the lymphocyte was isolated from spleen, and the absolute number of lymphocyte was counted with Haemocytometer. Results showed that the absolute number of lymphocyte on mice hypersensitivity after treated with ethanol extract of $D$. alata L. were the lowest, while the highest absolute number of lymphocyte was found in the group treated with antihistamine drugs followed by the group treated with diosgenin on $200 \mathrm{mg} / \mathrm{kg} \mathrm{BW}$, negative control group and control group, respectively.
\end{abstract}

Keywords: Balb/C mice, Dioscorea alata, ovalbumin, hypersensitivity, lymphocyte

\section{INTRODUCTION}

Purple yam (Dioscorea alata L.) is a source of nutritious tubers that has not been used optimally. Nutrients content in Dioscorea species are starch, essentials amino Acid, mineral, polyphenol, mucilage (glycoprotein), purin derivates (such as allantoin) and steroid saponin (Wanasundera \& Ravindran, 1994; Lape \& Treche, 1994; Agbor-Egbe \& Treche, 1995; Hikino et al.,1986, He et al., 1994; Hu et al., 1996; Hu et al.,1997; Yang et al., 2003; Wang et al., 2011; Yoon et al., 2008). D. alata L. contains diosgenin (Cheng et al., 2007), a main steroidal saponin steroid aglicon as intermediate steroidal in pharmaceutical manufacture. Steroidal saponin is the most important bioactive compound due to its biological functions such as anticarcinogenic, antithrombotic, antiviral, hemolitic, hypocholesterolemic, hypoglichemic, immunostimulatory, antitumorogenic, antimutagenic, immunomodulatory and antiinflammatory (He et al., 1994; Hu et al., 1996; Hu et al., 1997; Yang et al.,2003). Results of previous studies showed that steroidal saponin has antiallergic activity (Zhang et al., 2012). The purpose of the research was to assess the absolute number of lymphocyte on hypersensitivity of mice after treated with ethanol extract of Dioscorea alata $L$. tubers. 


\section{MATERIALS AND METHODS}

Experimental research on Balb/C mice with posttest only control group design. Independent variable is ethanol extract of Dioscorea alata tubers with different doses of $0.17 \mathrm{~g} /$ $\mathrm{kg}, 2.01 \mathrm{~g} / \mathrm{kg}$ and $10.04 \mathrm{~g} / \mathrm{kg}$. Dependent variable is absolute number of lymphocyte.

Twenty one male Balb/C mice were divided into seven groups: control $(C)$, negative control (NC), treatments with ethanol extract of $D$. alata L. tubers of $0.17 \mathrm{~g} / \mathrm{kg}, 2.01 \mathrm{~g} / \mathrm{kg}$, $10.04 \mathrm{~g} / \mathrm{kg}$ (T I - T III), treatment with antihistamine drug 0,4 mg/mice/day (T IV) and treatment with diosgenin $200 \mathrm{mg} / \mathrm{kg}$ (T V) (Huang et al., 2010). For 17 consecutive days the T IT III groups were treated with ethanol extract of $D$. alata correspond to with their doses, T IV group was treated with antihistamine drugs and $T V$ group was treated with diosgenin. On day 15 , the NC and T I-TV groups were induced with ovalbumin of $0,0483 \mathrm{mg} / \mathrm{mice}$ (Fischer et al., 2005 modified by Diding et al., 2008). Mice were sacrificed on day 18, the lymphocytes were isolated from spleen and the absolute number of lymphocytes from pellet suspension of lymphocyte was counted with haemocytometer 3 times on minor chamber. The formula for absolute number of lymphocytem is $\mathrm{N}=\mathrm{A} \times \mathrm{DF} \times 10^{4} \mathrm{sel} / \mathrm{ml}$, with $\mathrm{N}=$ number of lymphocyte, $A=$ number of a live/death cell mean/field of view, FP= Dilution Factor (10x).

\section{RESULTS AND DISCUSSION}

The results of measurements on absolute number of spleen lymphocytes of mice after treated with ethanol extract of $D$. alata tubers on various doses for 17 consecutive days and treatment model of allergic type hypersensitivity to ovalbumin on day 15 was shown in Table 1.

Results of this study indicated that the absolute number of lymphocytes of mice after treated with ethanol extract hypersensitivity of $D$. alata tuber was notably lower in the group with treatment dose of $10.04 \mathrm{~g} / \mathrm{kg}$ bw, while the highest absolute number of lymphocytes was found in mice treated with antihistamines followed diosgenin $200 \mathrm{mg} / \mathrm{kg}$ bw, negative control,and the control groups, respectively.

On hypersensitivity allergic reactions, cells which are crucial in determining types of reactions are antigen presenting cells and mast cells, whereas lymphocytes play a role in the early phase and late phase allergic response (Abbas \& Lichtman, 2011). However, results of this study indicated that in mice induced by allergic type of hypersensitivity to negative control group showed the absolute number of lymphocyte greater than the control group. Even in mice that induced allergies and were given with antihistamines, the absolute number of lymphocyte much larger, and so as to in mice induced by allergy and treated with diosgenin. The absolute number of lymphocytes was found in mice induced by allergic reaction and given the highest dose of ethanol extract $10.04 \mathrm{~g} / \mathrm{kb} \mathrm{bw}$, followed by induced allergic mice given ethanol extract dose and $0.17 \mathrm{~g} / \mathrm{kb}$ bw, and mice given the extract induced allergic and ethanol dose of $2.01 \mathrm{~g} / \mathrm{kb} \mathrm{bw}$.

Diosgenin is the main active compound in Dioscorea species and are structurally similar to cholesterol (Basch et al., 2003). Diosgenin levels vary among different species of Dioscorea (Datta et al., 1984; Huai et al., 1989). Diosgenin level varies on different species, growing techniques, harvesting, processing and storage conditions (Basch et al., 2003). 


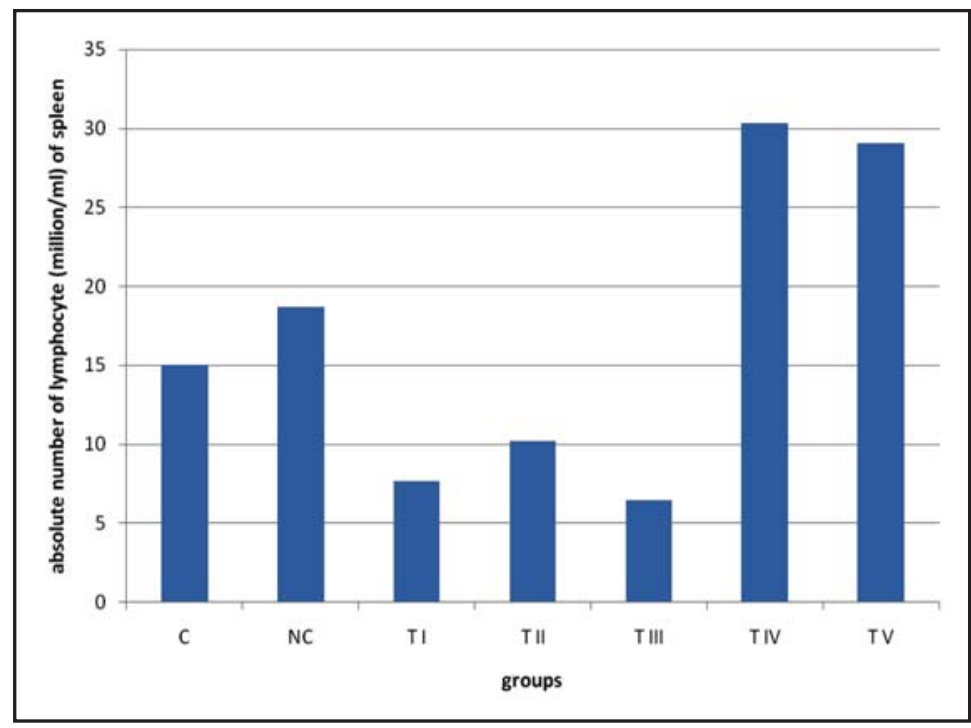

Figure 1. Absolute number of lymphocyte on spleen of hipersensitivity of Balb/C mice after treated with ethanol extract of $D$. alata $L$ orally (EEDA) for 17 consecutive days.

Note: C: control group, NC: negative control group, T I: EEDA 0,17 g/kg; T II: EEDA 2,01 $\mathrm{g} / \mathrm{kg}$, T III: EEDA 10,04 g/kg, T IV: antihistamine drugs 0,4 mg/mice, TV: diosgenin 200 $\mathrm{mg} / \mathrm{kb}$.

Saponin as adjuvant has the unique ability to boost immunity (lqbal et al., 2007). Saponin as adjuvant also has the ability to modulate cell-mediated immune system and increases the production of antibodies and has the advantage that it requires only a low dose of the adjuvant activity (Oda et al., 2000). Saponin adjuvant induces a strong effect on T cell-dependent antigen or antigens that are not dependent on T cells. Saponins also induce CD8 + cytotoxic lymphocyte responses are strong and provide a response to mucosal antigens (Kensil, 1996). Saponins not only have an effect on components of specific immunity stimulatory, but also have non-specific immune reactions, such as inflammation (de Oliveira et al., 2001; Haridas et al., 2001) and lymphocyte proliferation (Delmas et al., 2000; Yui et al., 2001).

Cellular immune response are activated to eliminate the allergen ovalbumin as allergic agents. Allergen provocation affects lymphocytes as cells that have the ability to regulate immune responses through modulation of $T$ cells and local tissue inflammation. Exposure to antigen presenting cells (APC) by ovalbumin will initiate the activation of CD4 + cells are Th2 and IgE synthesis, better known as the stage of allergic sensitization. The exposure of the next allergen ovalbumin orally will lead to the recruitment and activation of inflammatory cells and release of mediators that will cause an allergic response to both fast and slow phase. In the early stages of an allergic response, a few minutes after contact with an allergen occurs accompanied by the release of mast cell degranulation of inflammatory mediators. These mediators include histamine, leukotriene and cytokines that will increase the permeability of blood vessels, smooth muscle contraction, and mucus production. Chemokines produced by mast cells and other cells will directly lead to the recruitment of inflammatory cells. These chemokines will contribute to the slow phase of the allergic response characterized by the number of cells CD4 + Th2 and eosinophil (Holdgate \& Polosa, 2008). 


\section{REFERENCES}

Abbas, A.K., and A.H. Lichtman. 2011. Basic Immunology: Functions and Disorders of The Immune System. $3^{\text {th }}$ ed. Saunders Elsevier. Philadelphia.p. 8-13, 266, 107-109, 246.

Agbor-Egbe, T., \& S. Treche. 1995. Evaluation of chemical composition of Cameroonian yam germplasm. J. Food Compos. Anal. 8: 274-283

Basch, E., C. Ulbricht, D. Sollars, P. Hammerness, and S. Hashmi. 2003. Wild yam (Dioscoreaceae). J of Herbal Pharmacother. 3(4):77-91

Cheng, W.Y., Y.H. Kuo, and C.J. Huang. 2007. Isolation and identification of novel estrogenic compounds in yam tuber (Dioscorea alata Cv. Tainung No. 2). J Agric Food Chem. 55(18):7350-7358.

Datta, K., S.K. Datta, and P.C. Datta. 1984. Pharmacognostic evaluation of potential yams Dioscorea. J of Economic and Taxonomic Botany. 5:181-196.

Delmas, F., C. Di Giorgio, R. Elias, M. Gasquet, N. Azas, V. Mshvildadze, G. Dekanosidze, E. Kemertelidze, and P. Timon-David. 2000. Antileishmanial activity of three saponins isolated from ivy, alpha-hederin, beta-hederin and hederacolchiside $A(1)$, as compared with their action on mammalian cells cultured in vitro. Planta Medica, 66(4): 343-347.

de Oliveira, C.A.C., A.C. Perez, G. Merino, J.G. Prieto, and A.I. Alvarez. 2001. Protective effects of Panax ginseng on muscle injury and inflammation after eccentric exercise. Comp. Biochem. Physiol. 130(3):369-377

Diding, H.P., L.S. Endang, and A.A. Subijanto. 2008. Pengaruh probiotik terhadap gambaran histologis mukosa usus pada mencit Balb/C model alergi. J Kedokteran Yarsi. 16 (1):6-12

Fischer, R., J.R. McGhee, H.L. Vu, T.P. Atkinson, R.D. Jackson, D. Tome, and P.N. Boyaka. 2005. Oral and nasal sensitization promote distinct immune responses and lung reactivity in a mouse model of peanut allergy. Am. J. Pathol. 167:1621-1630

He, S., T. Zhan, and S. Wang. 1994. Study on chemistry and antioxidation activity of water soluble polysaccharides of rhizoma Dioscoreaceae oppositae. J. Chin. Pharm. Univ. 25: 369-372

Hikino, H., C. Konno, M. Takahashi, M. Murakami, Y. Kato, M. Karikura, and T. Hayashi. 1986. Isolation and hypoglycemic activity of dioscorans A, B, C, D, E and F; glycans of Dioscorea japonica rhizoporus. Planta Med. 52: 168-171.

Haridas, V., C.J. Arntzen, and J.U. Gutterman. 2001. Avicins, a family of triterpenoid saponins from Acacia victoria (Bentham), inhibit activation of nuclear factor-kappa B by inhibiting both its nuclear localization and ability to bind DNA. Proc. Natl. Acad. Sci. USA. 98(20):11557-11562.

Holgate, S.T., and R. Polosa. 2008. Treatment strategies for allergy and asthma. Nature Rev. Immunol. 8: 218-230

Hu, K., A. Dong, X.S. Yao, H. Kobayashi, ans S. Iwasaki. 1996. Antineoplastic agents I Three spirostanol glycosidea from rhizomes of Dioscorea colectii var. Hypoglauca. Planta Med. 62: 573-575.

Hu, K., X. Yao, H. Kobayashi, and S. Iwasaki. 1997. Antineoplastic agents II. Four furostanol glycosides from rhizomes of Dioscorea collettii var. Hypoglauca. Planta Med. 63:161165. 
Huai, Z.P., Z.Z. Ding, S.A. He. 1989. Research on correlations between climatic factors and diosgenin content in Dioscorea zingiberensis Wright. Yao Xue Xue Bao. 24(9):702706.

Huang, C.H., D.Z. Liu, and T.R. Jan. 2010. Diosgenin, a plant-derived sapogenin, enhances regulatory T-cell immunity in the intestine of mice with food allergy. J. Nat. Prod. 73:10331037.

Iqbal, R.Z., H.U. Song-hua, X. Chen-wen, A.G. Arijo. 2007. Adjuvant effect of saponins on animal immune responses. J. Zhejiang Univ. Sci. B. 8(3):153-161

Kensil, C.R. 1996. Saponins as vaccine adjuvants. Crit. Rev. Ther. Drug Carrier Syst. 13(12): $1-55$.

Lape, I.M., and S. Treche. 1994. Nutritional quality of yam (Dioscorea dumetorum and Dioscorea rotunda) fluors for growing oats. J. of Science of Food and Agriculture. 66 (4): 447-455

Oda, K., H. Matsuda, T. Murakami, S. Katayama, T. Ohgitani, and M. Yoshikawa. 2003. Relationship between adjuvant activity and amphipathic structure of soyasaponins. Vaccine 21 (17-18): 2145-2151

Wanasundera, J.P.D., and G. Ravindran. 1994. Nutritional assesment of yam (Dioscorea alata) tubers. Plant Foods Hum. Nutr. 46:33-39.

Wang, T.S., C.K. Lii, Y.C. Huang, J.Y. Chang, and F.Y. Yang. 2011. Anticlastogenic effect of aqueous extract from water yam (Dioscorea alata L.). J. of Med. Plants Res. 5(26):61926202.

Yang, D.J., T.J. Lu, and L.S. Hwang. 2003. Isolation and identification of steroidal saponins of Taiwanese yam cultivar (Dioscorea pseudojaponica Yamamoto). J. Agric. Food Chem. 51: 6438-6444.

Yoon, K.D., M.H. Yang, Y.W. Chin, J.H. Park, and J. Kim. 2008. Determination of allantoin in Dioscorea rhizome by high performance liquid chromatography using cyano columns. Nat Prod Sci 14 (4): 254-259

Zhang, T., C. Yang, P. Rupa, B. Jiang, and Y. Mine. 2012. Inhibitory effects of Quillaja saponin on IgE-mediated degranulation of rat basophilic leukemia RBL-2H3 Cells. J of Functional Food. 4:864-871

Yui, S., K. Ubukata, K. Hodono, M. Kitahara, Y. Mimaki, M. Kuroda, Y. Sashida, and M. Yamazaki. 2001. Macrophage-oriented cytotoxic activity of novel triterpene saponins extracted from roots of Securidaca inappendiculata. Int Immunopharmacol. 1(11):19892000 